\title{
$\mathbf{F} \cdot \mathbf{O} \cdot \mathbf{R} \cdot \mathbf{U} \cdot \mathbf{M}$ \\ Perspectives on Canadian Population
}

\section{Stationary population, immigration, social cohesion, and national identity: What are the links and the policy implications? With special attention to Canada, a demographer's point of view}

\author{
Anatole Romaniuk ${ }^{1}$ \\ This paper is dedicated to two of our distinguished colleagues-demographers, \\ no longer with us, professors Jacques Henripin and André Lux, \\ for their clear vision of what lies ahead if we fail demographically.
}

\section{Abstract}

In recent years, this author has devoted some of his research to the question of stationary population as a policy vision for Canada and beyond. The focus was largely economics and ecology. The virtue of the stationary population, it was argued, is that it cut across the long-term concerns of ecologists and short-term concerns of economists. The present paper, while reiterating some of the same economic arguments, addresses stationary population as a policy option from the point of view of national identity and social cohesion. To this end, it explores the policy and ideological dimensions of multiculturalism in Canada. It also examines immigration trends in Canada and Western Europe, and makes some incursions into the history of how cosmopolitan states have fared. The paper's conclusion is that stationary population is optimal in terms of national identity and social cohesion.

Keywords: population policy, population growth, John Stuart Mill, social cohesion, multiculturalism.

\section{Sommaire}

Ces dernières années, l'auteur a consacré certaines de ses recherches à la question de la population stationnaire au Canada et ailleurs dans le monde. L'optique en a été économique et écologique. La vertu de la population stationnaire, il a été soutenu, réside dans le fait qu'elle réponde aux préoccupations tant à long terme des écologistes qu'à court terme des économistes. Tout en réitérant ces préoccupations, la présente étude examine les attributs de la population stationnaires du point de vue de l'identité nationale et de la cohésion sociale. Dans ce but, l'étude explore les dimensions du multiculturalisme au Canada. Sont également

1. The author has been active in the field of population studies as a professional and academic for over 60 years, in Canada and abroad. As an escapee of totalitarian regimes, he had firsthand experience as a political prisoner, refugee, and migrant. Of dual ethnicity and dual citizenship (not related to his ethnic origins), he has lived in eleven different countries and is fluent in six languages. Among his many publications, of particular relevance to this paper's topic is the French-language article 'L'Europe face à son destin démographique' (Europe faces its demographic destiny) in Reflets et perspectives de la vie économique (1998: 83-99). This paper is a follow-up to some of the author's previous works, including "Stationary Population as Theoretical Concept and as Policy Vision," presented at the International Conference on Population in Marrakesh (September 2009, organized by the International Union for Scientific Study of Population, or IUSSP), and the article "Stationary population as a policy vision," published in Optimum Online: The Journal of Public Sector Management (2012). Correspondence: anromaniuk@yahoo.ca. 
examinés les courants migratoires au Canada et dans les pays occidentaux, tout en faisant des incursions dans l'histoire des sociétés cosmopolites, leurs réussites et leurs échecs. La conclusion de la présente étude est que la population stationnaire est optimale des points de vue de l'identité nationale et de la cohésion sociale.

Mots-clés : politique de la population, croissance démographique, John Stuart Mill, civilisation occidentale, cohésion sociale, multiculturalisme.

\section{Introduction}

In recent years, some of my research was devoted to the question of stationary population as a policy vision for Canada and for Western nations more generally. This led me to favour stationary population as the optimal response to the dilemmas of ecological and economic sustainability, in the spirit reminiscent of John Stuart Mill's philosophy on the stationary state: "It must always have been seen, more or less distinctly, by political economists, that the increase of wealth is not boundless, and that at the end of what they term the progressive state [lies] the stationary state..." (Mill 1965: 746; emphasis added). The virtue of stationary population, I have claimed, is that it addresses both the long-term concerns of ecologists and the short-term concerns of economists. However, I believe questions related to national identity and social cohesion also deserve attention when considering stationary population. A vigorous debate on population policies is required. All options should be on the table.

In demographic terms, stationary population is a configuration of zero population growth, with a reproduction rate slightly in excess of two births per woman (or, more exactly, 2.1, to compensate for mortality). This level of fertility would ensure the integral replacement of one generation by the next (Coale 1972). In more pragmatic terms, stationary population in the context of this paper is defined as a population that, in the long run, settles around a zero growth rate or a total fertility of two births per woman.

This paper is a prescriptive, normative type of demographic discourse. It is an advocacy paper. Many things said herein are matters of opinion. It is not all science per se. I wrote this piece as a long-retired demographer with worldwide experience in both academia and administration, and with an eye that transcends the narrow confines of demography to embrace its wider civilizational and geopolitical ramifications. On occasion, the language used is that of a polemicist, rather than cool academic neutrality. For from time to time, we need to indulge in "soft demography" for the benefit of public debates on population policies. While remaining true to our discipline, which in many respects is quantitative and analytical, one should not be scornful of more speculative, visionary ventures into the philosophical realm. We should also have the courage of our own opinions.

Indeed, this is also in keeping with the discipline of demography, since many demographers have similarly expressed their concerns or observations. Alfred Sauvy, the great French demographer, with his many writings on demographic subjects addressed to a variety of audiences, is a case in point. And Nathan Keyfitz, as much as he was a mathematical demographer, warned against the prevailing infatuation with the demometry that runs the risk of emptying demography of its very substance. So did the well-known Canadian demographer Jacques Henripin when twenty years ago, at the 1995 Symposium of the Federation of Canadian Demographers, he stated: "On peut se demander pourquoi les démographes - démographes canadiens en particulier - sont si valeureux du point de vue de la rigueur et si peu audacieux quand il s'agit de la santé démographique de leur société?" and implied that one of the reasons was fear of voicing one's opinion in public: "la crainte d'aller à l'encontre de certaines mythes vénérés par la société occidentale, nord-américaine surtout" (Henripin 1995: 307).

I will first present the immigration-related profile in Canada, and then explore the policy and ideological dimensions of multiculturalism in Canada and the Western world more generally. I will also make some incursions into history, to assess how cosmopolitan states have fared politically. Then, I will discuss some possible solutions to the sociodemographic conundrum of Canada and the Western world, in the spirit of the posited stationary population ideal.

\section{Canadian immigration, ethnic profiles and trends}

The following highlights are taken from the National Household Survey (NHS) for 2011, on the level and trends of immigration in recent years. Among the OECD countries, Canada has the second-highest proportion of foreign-born, representing 20.6 per cent of the population (6,775,800 out of a total of $33,476,688)$; Australia, at 26 per cent, is the leading country (see Table 1). Over recent years, net international migration has become 
Forum: Perspectives on Canadian Population — Romaniuk essay

the most important demographic component of growth for Canada. Between 2006 and 2011 alone, around 1,162,900 people immigrated to Canada. Roughly 661,600, or 56.9 per cent, came from Asia (including the Middle East), including 122,100 from China and about 121,400 from India. Prior to the 1970s, immigrants born in Asia accounted for only 8.5 per cent of the foreign-born population of Canada; today, there is an increased share of recent immigrants from Africa, Caribbean, and Central and South America, and these recent immigrants are relatively young compared to the Canadian-born population. In 2011, the vast majority of Canada's foreign-born population (94.8 per cent) lived in the Census Metropolitan Areas of Ontario, British Columbia, Quebec, and Alberta, with slightly over three-fifths (62.5 per cent) settling in Toronto, Montreal, and Vancouver. Nearly 6,264,800 people identified themselves as members of a "visible minority," representing nearly 20 per cent of all Canadians. South Asians constituted the largest overall visible minority group. Notably, 3 in 10 visible minorities were Canadian-born.

What do these highlights tell us about immigration and Canada's national ethnic profile in recent years? Against the background of growing ethnic heterogeneity in Canada's population, immigrants are young and represent a dynamic, entrepreneurial, and innovative segment of the population. By contrast, the Canadianborn are older (and by implication presumed to be more conservative). Immigrants are settling in the large cities, Toronto, Montreal, and Vancouver-places in the vanguard of social change, and wielding economic and social-political dominance.

Seen from a historical perspective, immigration under a variety of categories - economic, family, and humanitarian, both permanent and temporary-has reached record numbers in more recent years (since about 1986). Immigration presently constitutes the bulk of Canada's population growth. While in the period 1951-91 net migration accounted for about one-quarter of population growth, it accounted for more than 60 per cent of growth in the period 1996-2011 (Beaujot and Raza 2013: 147).

Historically, immigration was not only substantially smaller, it also took place in a demographic environment where the Canadian-born population enjoyed a relatively high birth rate. This is no longer the case. Hence, the higher levels of immigration are taking place in an environment where the Canadian-born population has lowerthan-replacement fertility. Interestingly, first generation newcomers to Canada, and their children in particular, demonstrate a fertility rate that is as low as, if not lower than, that of Canadians generally. What this means is that in order to maintain the population at its present level, let alone for it to grow, Canada needs to bring in an ever-growing number of immigrants. Should this trend persist over the long term, the three founding nationsFrench, British, and First Nations_-may become marginalized. "Lorsque les immigrants se substituent aux naissances de façon massive, la société hôte se fait progressivement remplacer par les nouveaux venus et leurs descendants et elle finit, à toute fin utile par disparaitre," wrote Henripin (1989: 119). According to a microsimulation performed by a team of Canadian demographers from Statistics Canada, "one hundred years after the beginning of the projection (2006), between 62 and 88 percent of the population would have either immigrated to Canada after 2006 or would be a descendant of someone who immigrated to Canada after 2006" (Dion et al. 2015: 118).

\section{The Western perspective}

What is true for Canadian immigration is generally true for what we often call "the West" as well, and in some cases more so. Table 1 shows the proportion of foreign-born for the most economically advanced countries. As already mentioned, Australia and Canada rank highest, with the percentage of foreign-born representing 26.8 and 20.6 per cent of the total population, respectively.

Table 1. Foreign-born population as a proportion of the total population in G8 countries and Australia

\begin{tabular}{lccccccccc}
\hline Country & $\begin{array}{c}\text { Australia } \\
(2010)\end{array}$ & $\begin{array}{c}\text { Canada } \\
(2011)\end{array}$ & $\begin{array}{c}\text { Germany } \\
(2010)\end{array}$ & $\begin{array}{c}\text { USA } \\
(2010)\end{array}$ & $\begin{array}{c}\text { UK } \\
(2010)\end{array}$ & $\begin{array}{c}\text { France } \\
(2008)\end{array}$ & $\begin{array}{c}\text { Russia } \\
(2002)\end{array}$ & $\begin{array}{c}\text { Italy } \\
(2009)\end{array}$ & $\begin{array}{c}\text { Japan } \\
(2000)\end{array}$ \\
\hline Proportion & 26.8 & 20.6 & 13.0 & 12.9 & 11.5 & 8.6 & 8.2 & 8.0 & 1.0 \\
\hline
\end{tabular}


The scope of this paper prevents us from going into a more complete analysis of immigration and socioethnic profiles of Western democracies, but a few glimpses will suffice for our purposes. In the United Kingdom, for example, according to the British demographer David Coleman, the "ethnic composition would be radically transformed within the current century" should immigration trends continue. "By mid-century the non-white population would increase to 24 million (31 per cent) and the Other White minority by 7 million (10 per cent). ...the white British population would have fallen below half by late 2060" (2010). Note the current (2014) population of the United Kingdom is 64.5 million. This also applies to other Western countries, with some variations - notably France. In others, such as Netherlands and Sweden, populations of foreign origin are expected to comprise the majority of the population by the end of the century. ${ }^{2}$

One thing stands out clearly when seen from a historical perspective. From a continent of emigration, Western Europe has become a continent of immigration. This is in itself an important turning point, with farreaching implications for the Western world. Though Canada and the U.S. were obviously countries of immigration, the origin countries have shifted over time, from Western Europe to Eastern and Southern Europe, and in more recent years to non-European countries. ${ }^{3}$

How do we explain the rise of immigration in both quantity and heterogeneity in Western countries? There is no simple answer to this question. It is a combination of causes-demographic, economic, and also ideological, with the latter perhaps being most important from the point of view of the role it plays in compelling policymakers to opt for heightened levels of immigration and heterogeneity. ${ }^{4}$

\section{Ideological controversy: globalism and diversity versus national identity and social cohesion}

The post-war baby boom and ensuing population growth, which inspired so much optimism about the demographic future and prosperity of the Western world, were short-lived events. As of the mid-sixties, demographic trends resumed their pre-war secular decline and the economy underwent an unsettling stagflation in the seventies, followed by successive recessions. In most Western countries, including Canada, fertility settled at subreplacement levels, arguably becoming enduring features of Western demographics. Preoccupations with potentially imploding populations, labour shortages, and ageing, along with concerns for the sustainability of pension flows, began to haunt policymakers. Rather than embarking on a policy of boosting fertility, an option considered costly and potentially ineffective, concerned countries determined that it would be more expedient to resort to ever-increasing immigration. Immigration thus became the palliative solution for all problems, real and imaginary, that beset Western societies. After a comprehensive review of a wide range of literature on the subject, the demographer Termote came to the conclusion that "two of the basic objectives of immigration policies" —economic (per capita income) and demographic (counter aging) _ “....are not [being] met” (2011: 105). Dubreuil and Marois reached a similar conclusion in regards to Québec in their book, Le remède imaginaire: Pourquoi l'immigration ne sauvera pas le Québec (2011). Yet, this notwithstanding, there is a lingering perception that an ever-growing and ever-larger population is both a prerequisite to economic progress (in the sense of per capita enrichment) and a way of projecting national might on the international scene. Hence, the populationist agenda is thus driving population policy.

Although, as stated earlier, large-scale immigration to a country whose native population no longer reproduces itself is bound to radically change the cultural and ethnic make-up of that receiving country, this trend is not being readily recognized or admitted as a concern. First, immigration is in keeping with the professed ideal of

2. For an update on immigration and the changing ethnic mosaic of the European Union, see the excellent analysis by the Romanian demographer Vasile Gethau (2016).

3. These Western trends are in stark contrast to what is happening elsewhere, for example in Japan. Whereas the foreignborn population is in the double digits in Western countries, Japan posts a modest $1 \%$ of foreign born. Is therefore Japan to be judged as a socially, economically, and democratically less advanced country?

4. For a remarkable, uninhibited yet judgment-neutral analysis of immigration and its implications, the reader is referred to two books, Population Change in Canada (2016) by Don Kerr and Roderic Beaujot, and Canada's Population in a Global Context: An Introduction to Social Demography (2015) by Frank Trovato. It is from these two books that this author drew information on Canada's immigration and its ethnic composition. For an update on population and immigration policy in Canada, see Beaujot and Raza (2013). 
Forum: Perspectives on Canadian Population — Romaniuk essay

the transnational state, as articulated by proponents of critical theory and postmodernism such as Derrida (2002) in France and Habermas (2000) in Germany. Second, adherence to principles of equality - the UN Charter of Human Rights, and more generally to the Western liberal tradition (Fukuyama 2007)—ensures acceptance of diversity in terms of national origin. Third, there are economic forces at work globally, namely, the insatiable desire for workers in an ever-expanding economy, in a context of growing global inequality between have and have-not countries. Fourth, political parties in Western democracies are competing for the support of minorities. Fifth, another important reason is the devaluation of national values and nihilistic mindset in the Western world towards its national history and the idea of the nation itself (Ferguson 2011). As a result of these combined forces, in Western countries multiculturalism has come to be erected as official policy, with Canada in the lead.

The rationale underlying multiculturalism is well intended. However, I have serious concerns about this ideological perception of nationhood. First, the term multiculturalism is itself a misnomer, for it has nothing to do with culture per se (other than pizza and perogies). And the more recent concept of interculturalism, implying groups' mutual cultural adaptation and sharing, does not make matters simpler. It is untenable in its very substance. It claims intrinsic virtues as a vehicle of nation building, "Unity in diversity." Yet this is more easily said than done. History is replete with bloody conflicts, and it does not take much to realize that the root cause of many of the world's conflicts is precisely the very diversity that is being elevated by some to a unifying virtue. The truth is that diversity is a very complex construct, one that cuts both ways. It can bring richness just as it can bring destruction, and therefore it has to be handled with the utmost care. The policy of diversity cannot be simply thrust or forced upon people in the name of an ideology. ${ }^{5}$

What is occurring under "multiculturalism" is the creation of new instant artificial societies, created on the formality of citizenship, thus superseding the notion of historical nations, which took centuries to evolve into nationally conscious communities of peoples. The historical records of artificial states are not encouraging. For instance, the Roman Empire fell into decay as it became increasingly cosmopolitan, as we read in The Decline and Fall of the Roman Empire by the great British historian Edward Gibbon (1989, 1848). There are examples closer to our time. Austria's multinational empire, as deferential as it was to the distinctiveness of its various nationalities, was defeated in the First World War. The multinational Soviet Union, a totalitarian state facing centrifugal national forces, ultimately collapsed. Even more recently, there is the case of Yugoslavia; and the unity of Spain seems under constant strain with Catalan and Basque attempts to opt out. Belgium, otherwise a highly prosperous and progressive country, would have long split along ethnic lines-Walloon and Flemish-were it not for its monarchy, which somehow keeps the country together. And then, who could have expected that a stable and liberal country such as the United Kingdom, with its conservative mindset abhorring radical changes, would be at risk of splitting along ethnic lines, with Scotland opting out (Kim 2005), not to mention the almost perennial ethnic conflict in Northern Ireland. The European Union itself- the great multinational construct that came into being after centuries of inter-European fratricidal wars, culminating in the cataclysmic human slaughter and material destruction of World Wars I and II-is under considerable strain. As for Canada, I leave it to readers to reflect — with a reminder not to forget the 1980 and 1995 Quebec referendums on national sovereignty; the "Non" side during the latter was carried by only 50.58 per cent of the votes.

Far from being Manichean by painting everything either black or white, I do acknowledge that there are variations and nuances, of course. Belgium is still a federal state, Switzerland is seen as a successful confederation, and the case of India is particularly revealing, as I wrote in my review of the book by a distinguished IndoCanadian demographer, Parameswar Krishnan, Glimpse of Indian Historical Demography:

India throughout history has had its share of upheavals, wars, occupations, and civil unrests that have brought suffering and devastation. The latest of these were the massive displacement of populations, the partitioning of the country following independence from British rule, and even today, ethnic, religious, and social conflicts are not uncommon. But on the whole, since independence India has worked out viable accommoda-

5. Parenthetically, I have noticed that the very people who promote the idea of diversity are those who stand for national and colonial liberation. I have no problem with that; however, these same people are implicitly telling Canadians that they have no monopoly on the land they occupy historically, and that they have to share it with people from other lands, whatever their numbers and prospects of integration may be. 
tions that allow this multi-ethnic, multi-linguistic, and multi-religious country to maintain internal peace and to uphold democratic values (Romaniuk 2013).

In the Western European countries, large sectors of the inhabitants feel threatened by immigration from non-Western origins and the rising levels of ethnic diversity in their societies. Countries that are ethnically diverse are difficult to manage (Paquet 2008, 2010). Massive immigration in Western countries has become an explosive issue, as recent events in France, Germany, and Belgium have demonstrated. ${ }^{6}$ As I have previously argued:

Scarcely has a subject given rise to so much passion and polarization of public opinion as immigration, even though we are all the product of a mixing of peoples throughout human history. Migration has without a doubt contributed to genetic crossbreeding and cultural pollination. Its economic contribution is rather highly rated. Lately, however, a hardening of public opinion can be observed everywhere towards immigration-and not only towards clandestine immigration, which is taking on worrisome proportions. Long the battle cry and target of extremists and xenophobes, immigration is about to become a legitimate concern of centrist political currents, more representative of general public opinion (Romaniuc 1998: 93; translated from the original French).

Britain's decision to leave the European Union, and the surge of the Trump phenomenon in the USA, are the most recent manifestation thereof. Debates on the subject are by no means easy, as revealed by the following passages, taken from an earlier article by this author:

We tend to confuse individual and collective attitudes and behaviours towards alterité. Whereas a thoughtful individual would transcend colour and creed to see at the deepest level a human being and act accordingly, at the collective level the dynamics at work are different_ones over which we as individuals have practically no control. Likewise, we tend to ignore the power of nature: you close one loop, and nature breaks out through another. Immigrant minorities' attachments to national, ethnic, religious or cultural values remain strong for generations, particularly if they come from a culture that is alien to that of the host country. They tend to cultivate their uniqueness and eventually become assertive as they reach a critical mass (Romaniuk 2012: 7).

Nations, and their interests, remain the cornerstone of international relations, notwithstanding trends to form supranational structures (Smith 2000). With all the globalist rhetoric, the world is getting more and not less nationalistic, if not in waning Western democracies than certainly in all other parts of the world where there is the growing sense that it is their turn to make history. The much longed-for Kantian "eternal peace" remains a remote proposition. And as much as we may admire the idealism of some, such as political philosopher Joseph Carens (2014), who advocates "open country borders" (albeit for economically developed countries only) in the name of human rights, we need to look to the reality of the world as it works. The transnational state-society may be just a delusion. Immigrants and their immediate descendants, no less than Canadians de souche, long for a stable, prosperous country. They recognise the importance of social cohesion and national identity. Prosperity, peace, liberty, rule of law, and civic tolerance are what brought so many migrants to choose Canada.

While singling out national identity as an issue in discussions of multiculturalism and immigration, the intention is not to elevate nationhood to sacro-sanctity, locked forever in time, or to close the door to the transnational movement of people. Not all is wrong with diversity as a social construct. Respect for another's culture is a virtue in itself. Diasporas, in many cases, can play a positive role in interstate relations, and in mutual enrichment through cross-fertilisation. Nor does this author lack empathy for immigrants and refugees. $\mathrm{He}$ is one of them. To extol the virtues of diversity is more a matter of political correctness or expediency rather than based on a sober analysis or deeply felt conviction. The matter is not one of "all or nothing," but that of degree. It all boils down to the question of what French humanist, writer and philosopher Albert Camus (1951) encapsulated in two words, "mesure et démesure" (Romaniuk 2012: 7).

What that "mesure" is will be the topic of the next section.

6. To reduce the problem to an issue of the "extreme right" seems misleading. "For if we look to the European Union as a catchall solution, chanting 'Europe!' as a mantra and waving the banners of 'Europe' in the face of the recalcitrant 'nationalist' heretics, we may wake up one day to find that far from solving the problems of our continent, the myth of 'Europe' has become an impediment to recognizing them” (Judt 2015: 46). These words are those of the renowned British historian Tony Judt, who could hardly be suspected of nationalism. 
Forum: Perspectives on Canadian Population — Romaniuk essay

\section{In search of the optimal solution to the socio-demographic conundrum of the Western world}

A number of things are in need of reconsideration in order to find a response to the population conundrum worldwide and in the Western world in particular. First, we need to downplay the populationist agenda which postulates that growing and large populations are the forces that move economies forward and project a nation's international might. In no way can Western countries match the population size of the world's two demographic giants-China and India-with their respective 1.4 and 1.3 billion populations (2014). The two countries together already represent almost 40 per cent of the world's seven billion population (2014). Africa's population, too, stands now at 1.1 billion and is expected to grow to 2.4 billion by 2050, with the lion's share going to sub-Saharan Africa. Its population is growing at a staggering annual rate of 2 to 3 percent (Romaniuk 2011). By comparison, Europe's population, taken as a whole (Russia included), is progressively shrinking relative to the world's population from, 22 per cent in 1950 to 10 per cent in 2014, and it is expected to fall to less than 8 per cent by 2050, according to UN projections (medium variant). Europe's population, which doubled Africa's in 1965, is expected to be half the size of Africa's population by 2025. In terms of population size, Nigeria will overtake the United States and Ethiopia will overtake the Russian Federation by mid-century. What is true from a demographic perspective is also true from an economic perspective. The European Union is retreating as a world economic power. Its GDP went down from 40 per cent of the world's production capacity in 1900 to 25 per cent in 2000, and is expected to slip to 10 per cent by 2050 .

Hence, whoever studies geopolitics cannot ignore the global demographic and economic contexts and tectonic shifts taking place. "The revolutionary demographic changes that the world is experiencing are impacting virtually every aspect of human life. Ignoring those weighty consequences and avoiding the needy adjustments to the changing demographic landscapes will significantly impact societal wellbeing," writes the keen observer of the demographic world scene and former director of the United Nations Population Division, Joseph Chamie (2015b).

There is a great deal of discussion nowadays about migration. Immigration no doubt has its role and importance for both the origin and host countries, as the authors of The Age of Migration have so well articulated (Castles et al. 2015). While immigration is not a solution to all our social and economic problems, it can be a part of it. A liberal society by its very nature cannot be a closed society. As for immigration in particular, let me recall the words that the Belgian-Canadian demographer André Lux pronounced at the above-mentioned Symposium:

The growing importance of immigration from the point of view of demography, economics, and social fabric requires more in-depth research on this dimension of our present and future life as a society. Immigration should not be manipulated along short-term conjunctural factors; it requires a long-term approach, based on a clarified vision of the type of society we want to build, with what sort of identity. By not addressing this issue in fear of breaking some taboos, we might be paving the way to toward an increasingly "artificial" Canada (Lux 1996: 321).

In terms of material wealth, the Western world, especially, has already reached a level high enough to pay more attention henceforth to matters of quality of life, including the issues of internal social harmony as well as internal and external security. Moreover, we should stop romanticizing the myth and the image of the migrant. Man is an atavistic animal, deeply attached to his roots, to his place of birth. Forever going to faraway places, leaving behind loved ones and erasing the memories of childhood, is a painful experience that shadows one's whole life, no matter how otherwise satisfactory the new places may be.

Immigration may not be as important a factor in economic growth (defined in terms of per capita enrichment) as is often claimed (see, for example, Francis 1982). Postwar Japan and Germany are excellent illustrations. These countries rose from the ashes of World War II to become world economic powers; their cities had been levelled to the ground and their male populations severely depleted, while millions of German soldiers died or were held prisoner for several years after the war, particularly in the Soviet Union. Meanwhile, millions of ethnic Germans who were expelled by the Soviets from the eastern territories they occupied, crowded West Germany, which was under the much more benevolent occupation of Western powers. Further, whatever was still left of German industry after the war was literally dismantled and plundered by the Soviets. 
Neither was the Marshall Plan—as much as it was an expression of American political wisdom and generosity to a shattered Europe - a significant factor in Germany's economic recovery, the Wirtschaftswunder. It was the monetary reform of 1948 that triggered the recovery, under the good governance of postwar West Germany. Only later were immigrants brought in under the "Gastarbeiter" (guest worker) program, first from Southern Italy and then from Turkey and many other southern countries. They happened to be a particular brand of guest, as they never left Germany, not swayed even by generous financial compensations meant to encourage repatriation. In the meantime, Japan's economic miracle came about with no immigrants at all.

But why go to these and similar historical antecedents when such authoritative bodies as the Economic Council of Canada finds that higher levels of immigration have little if any per capita effects (1991). Economists, like Denton and Spencer (2003), to mention just these two, have come to similar conclusions. Yet the vaunted virtues of immigration persist unabated. As the leading Canadian demographer, Jacques Henripin (2011: 55) puts it in his sardonic way: «Et bien! cela n'a pas empêché presque tous les chantres politiques de claironner pendant deux décennies que le Canada avait besoin de plus d'immigrants pour des motifs économiques». And then immigration's economic benefits, if any, have to be weighed against potential ecological and social costs. We will return to this point later.

Much in economic terms can be generated today without labour, owing to spectacular advances in laboursaving automation, robotic technology. Advances in wireless communication make possible the almost instantaneous transfer of knowledge and skill (Sowell 1983, 1996). Japan already makes great use of these labour-saving technologies. Much of the work can and actually is outsourced to cheaper labour countries, for their benefit. "Innovation, not population will be the base of power. The idea that stagnant or shrinking workforces would doom the West must be rethought, now that more and more jobs are being replaced by robots and algorithms," argues Katinka Barysch (2016). Last but not least are the significant productive potentials of a growing elderly population that enjoys good health in highly developed countries (McDaniel 1996; Légaré 2001).

There is also the question of a more equitable distribution of wealth worldwide. Canada and other Western countries can and should devote part of their resources to the vigorous support of developing countries_again, primarily in Africa - to speed up the fertility transition and thus generate the demographic dividend regarded as a potentially important factor in their economic take-off (May 2012). But substantially bolstering today's poor countries does not imply making wealthy countries less wealthy. A more equal wealth distribution would reduce migration. For example, there is less interstate migration within the European Union, despite freedom of movement for citizens of the Union.

Finally, we should be mindful of the ecological health of our planet—an overriding long-term agenda in managing the well-being of the planet (Daly and Cobb 1989; Jackson 2009; Suzuki 2009, 2011). There are limits to population growth at least in the intuitive sense, even though we cannot put a figure on it. Nor should it be assumed that so-called "empty spaces," in reference to Canada or Australia, ought to be populated. It is this author's view that these "empty" spaces are empty only in a relative sense; they, as those of the Amazon and equatorial African forests, ought to be preserved for the ecological health not just of the countries concerned but for the world (Gerkens 2015). "Evidence over the past decade has shown that forest destruction is a critical source of the heat-trapping gases that cause global warming," wrote the great Canadian environmentalist David Suzuki (2009: 122). Some highly developed countries with high population densities may actually benefit from population reduction by somewhat alleviating the pressure on space that arises from overcrowding. Japan is a case in point (Kono 2009), as are Great Britain, the Benelux, and Germany. In short, while not being the panacea for all the problems affecting nations and the world more broadly, a stationary population is, in this author's view, part of the solution.

There is yet another important dimension to be considered. While so far downplaying the perceived importance of immigration as a factor in national economies, there is yet something to be said about reproduction. In fact, this is the heart of the matter. The world, at various degrees and speeds, is moving to what may be called the regime of demographic maturity, whereby people live longer and healthier lives, and reproduce themselves less and less (Chamie 2015; Romaniuk 2010). That is the regime of sub-replacement fertility. It is not that humanity has lost its maternal or parental instinct; rather, as it is today, the disincentives to maternity are far too great. Women in developed countries and throughout the modernizing world are now faced with many deterrents to maternity (marital instability, financial insecurity), on the one hand, and many fulfilling opportunities, professionally and 
Forum: Perspectives on Canadian Population — Romaniuk essay

financially, on the other. They are left with little incentive to trade these liberating forces against the burdens and uncertainties of motherhood (Perelli-Harris 2005). The alternatives to motherhood in today's modern society are just far too attractive to be resisted. The modern woman is being asked the impossible: to be equal to men in all spheres of life, even as a fighting force in war, yet she is still expected to be the giver of life, bearing and raising children, without which there is no humanity.

So what is the alternative? There is a need to reassess the place of motherhood in modern society. Motherhood should be much more fully rewarded, commensurably, morally, and materially, and this in the name of both distributive justice and demographic sustainability. Indeed, it can be done, thanks to the wealth that modern societies enjoy. It is often claimed that family allowances and similar incentives lack the force of sustaining reproductive propensities. (For an enlightening assessment of family support policies in liberal states, see McDonald 2006.) The truth of the matter is that these various incentives are more of a welfare addendum than designed to actually stimulate childbearing. Even so, in countries like Sweden and France, where family assistance are comparatively generous, fertility is actually higher, close to the replacement level. But much more remains to be done to maintain fertility at replacement levels in the long run, even in France and Sweden. In fact, there is a need to redefine motherhood and childbearing from being a private good to being a public good, without calling into question individual or women's rights or freedom of choice. Hand in hand with the financial rewarding of motherhood goes work flexibility for employed mothers, to fully accommodate parental responsibilities. Granted, there are still glaring gender inequalities throughout the world, even in the most economically and socially advanced countries (Chamie 2015). Yet, it is primarily mothers who face discrimination. Hence, it is here that correctives are overdue.

To address this situation, I would advocate that all mothers should be paid the equivalent of their salary for a significant period of time, both to encourage them to become mothers and to ensure that they do not suffer discrimination and penalty for choosing motherhood. We are told that the economy cannot afford this, though no serious study has been carried out to prove the point. There were great debates, we may recall, in the late nineteenth century in Western countries about the feasibility of universal education at the primary level. Yet it proved to work, in spite of widespread pessimism at the time. On a more general level, there is a need to rethink the balance in the allocation of resources between production and reproduction. So far, the former is being privileged at the expense of the latter. There is an urgent need to redress the imbalance, to forestall sub-replacement fertility turning into a permanent feature of economically advanced societies.

The family is central in any policy aiming at demographic recovery. All demographic adjustment passes through the family. The family remains the only institution capable of optimizing procreation and the socialization of children, thus, the organic reproduction of society. Humanity has not found valid substitutes. Shaken in its biological foundations, undermined and trivialized as a social institution, the family is not doing well of late. And it is not with negative measures, such as making divorce or abortion inaccessible, nor with electorally flavoured slogans on family values, or through a venal and narrow pro-natalism, that the family will recover its vigour. The efforts to renew it must be combined on several fronts-spiritual, legislative, social, and economic. Family law, which has been bastardized by erratic legislative initiatives, needs to be completely recast, as well as the tax system that accompanies it. Like any individual, the family also aspires to be recognized. Often, this recognition is not given it, in the name of individual universal rights and of the equality of all forms of unions, including pseudo-conjugal ones.

Material and institutional support to the family must be multifaceted in order to be efficient. It must be an investment in what economists call buman capital, i.e., the health and education of children. It must facilitate the double role, that of the relative and that of the professional. It is also a means to equalize income between men and women. It is only legitimate that women be compensated for the economic shortfall or demographic cost they bear as mothers. In other words, to be accepted by public opinion and to have a chance to succeed, a family policy must uphold social equity (gender equality), economic rationality (human capital), and demographic considerations (reproduction of society). It is then a matter of giving back to the family its pre-eminent social function in the perpetuation of the human species and in the socialization of progeny.

There are two related questions that remain to be touched upon briefly. What is being advocated here is the society's demographic stationary configuration. This means having about two children per woman as an integral 
generational replacement norm. That is on the assumption that each woman will have just two babies. In the current modern society, some women, maybe as many as 25 per cent, will choose not to have children. Some will do so for health reasons, others for reasons related to the absence of partners (as one would expect in our anonymous societies and in the absence of strong family ties), or because of their commitment to their profession or vocation, or for a variety of other reasons, all of which are entirely legitimate. This means that women who choose motherhood would need to produce, on average, three rather than two babies. The three-sibling norm also seems optimal from the point of view of child socialization.

When considering childbearing and motherhood in modern society, one inescapably also runs into the single mother phenomenon. Regardless of one's opinion as to whether the two-parent family is the preferred setting for childbearing and child raising, the reality is that as much as roughly one-quarter of Canadian mothers are single mothers, by choice or by circumstance. They deserve moral and financial support. For the reality is that stable marriage, the precondition of raising fertility, is problematic in Western societies for a number of reasons. With traditional large families gone, the matchmaking role often played by siblings is now replaced by a proliferation of for-profit agencies. The entirely laudable policy of encouraging both men and women to be equally ambitious in the public realm has also had some unexpected consequences. There has been much written over the last decade, for example, about the fact that many women are now much better educated than the men in their social circles, creating challenges around finding suitable mates. Moreover, a good segment of the male population in rich countries in prime marriageable age cannot afford marriage and a family because of their economic insecurity. This is particularly true for blue-collar young men (Economist 2015).

This being said, boosting fertility even to the generational replacement level is a daunting task. Any sustainable pro-family policy faces tremendous obstacles. Yet, the French and Scandinavian experiences suggest that childbearing support programs can work when they reach a critical impact level. Obviously, no policy can last forever. It has to be innovative and adapted to the prevailing conditions and ever-changing societal contexts.

Then there is Canada's history and its continuity, whatever population policy is put in place. The two founding nations, English and French, are and ought to remain the country's national backbone. Nor should any Canadians - immigrants and their descendants — forget what they owe to the First Nations, the first known inhabitants of this land. They have not always been on the benevolent side of history (Romaniuk 2014). While largely leaving the door open to the transnational movement of people — as advocated, for example, by the Canadian demographer Alan Simmons (2010) — policy makers should avoid turning Canada into a nation of immigrants, a demographic conglomerate being constantly renewed by an ever-growing number of immigrants. Economically developed nations have already reached a high enough level of wealth and should pay henceforth more attention to quality of life, to internal social harmony and external security.

\section{Concluding comments}

This paper argues that stationary population is an optimal demographic configuration on economic grounds, as well as from the point of view of national identity and social cohesion. To this end, the policy and ideological dimensions of multiculturalism in Canada were explored. Incursions were made into history regarding how cosmopolitan states have fared. The current literature tends to emphasize concerns over the aging population, depletion of the domestic labour force, the potential decline in population, and deleterious effects on the economy, including the sustainability of pension funds. Large-scale immigration is often seen as a remedy to these problems. The pro-populationist stance remains part of nationalist ideologies across the globe, even among democratic nations.

While not denying the validity of the rationales behind some of these claims, this paper emphasizes the importance of quality of life in societies that have already reached a high standard of living. Hence, the paper claims that efforts should be directed at improving the quality of life. To quote Mill again, "It is scarcely necessary to remark that a stationary condition of capital and population implies no stationary state of human improvement... Only when, in addition to just institutions, the increase of mankind shall be under the deliberate guidance of judicious foresight, can the conquest made from the powers of nature by the intellect and energy of 
scientific discoverers become the common property of the species, and the means of improving and elevating the universal lot" (Mill 1848: 751).

Quality of life includes personal security and social harmony. As Jacques Henripin (2011: 57) wrote in pondering over the amount of migratory intake to Canada, «Ily a des quantités à ne pas dépasser, si l'on veut maintenir une cohésion sociale minime... » Under a stationary scenario, the need for immigration would be lessened and the integration of migrants into mainstream society would be easier, thus alleviating legitimate concerns about national identity and potential social conflicts. In contrast to the prevailing concern with demographic aging, the author sees virtues in the significant productive potential of a growing elderly population that enjoys good health.

Developed countries, especially Western countries, need to direct substantial resources to bave-not countries in order to enable them to escape the Malthusian trap, trigger their economic take-off, and thus diminish economic disparities between have and have-not countries, which is the prime cause of the population exodus toward richer Western countries. Particularly important is the prevention of a massive brain drain from developing countries. Without domestic human capital, these countries cannot move forward. "Nothing is simple in this world. In solving a problem more or less satisfactorily, we create many others. The previously mentioned problem of project financing is an example. At a time when the welfare state is already accused of so many sins, would it not be a mess to extend its jurisdiction to maternity? And what about the massive and uncontrollable immigration that we have lamented? Would a country that is so generous not become a Mecca for all the poor mothers from faraway lands, and also... for refugee women, persecuted for wanting to exercise their fundamental right to procreate (the one-child political case in China)? A fundamental reassessment of the national product distribution criteria and of the national budget priorities will undoubtedly be required when society comes to grip with the imperatives of a mature demography. As for the potential loss of control of the migratory flux, this is essentially a matter of immigration portfolio administration (Romaniuc 1998).

Given this paper's conclusion that stationary population policies are optimal for maintaining national identity, social cohesion, and material well-being, the question remains whether the robust pro-family policies to achieve childbearing at the generational replacement level are doable. Under the regime of demographic maturity emerging in modern societies, people live longer and healthier lives but reproduce themselves less and less. Many are indeed sceptical that a pronatalist policy can be successful in the end (Gauthier and Hatzius 1997). I am more optimistic in this regard, citing Sweden and France as examples, and argue that the role of national elites, civil and religious, should not be underestimated in shaping national policies. France in particular may serve as a model, with its Institut national d'etudes démographiques, under the stewardship of the great demographer and visionary, Alfred Sauvy. Not through propaganda but by the force of years of systematic studies initiating and monitoring specific population and family-related programs, the effort of redressing France's demography ultimately bore fruit. The long-standing French mindset of "doing nothing," and doubt whether anything can be done in matters of population, has been reversed. France has transformed itself from a century-long demographic stagnation into a dynamic demography relative to other Western countries, at least for now. This said, like other countries of the European Union, France has to contend with the significant challenge of integrating a growing diverse immigrant population into French society (Tribalat 1955, 2010, 2013; Zemmour 2014).

The bigger picture is in Western Europe. This corner of the Euro-Asian land mass is under heavy demographic pressure from neighbouring regions, where immigrants, refugees, and those seeking a better life originate. Africa, with its fast-growing impoverished population, is potentially the biggest source (May 2016). The Middle East and beyond, suffering political turmoil and violence, some the making of Western powers, is yet another. Eastern Europe, what was the Soviet Union, is at risk of turning into a zone of instability, as current events in Ukraine are demonstrating. Immigration to Western Europe and the countries of the West, including Canada, is taking place against a demographic background of a sub-replacement reproductive regimes. As well, there are various symptoms that the Western world's economy may enter a long wave of depression, a kind of Kondratieff economic

7. Foreign investment is important, but in the absence of strong domestic human capital in the form of an intellectual and political elite, foreign investments can turn the receiving countries into neocolonialism under guises not yet seen. Thus, how it can be done effectively is still a matter of contention. For a critique of foreign aid to developing countries, refer to the Nobel Prize-winning economist Angus Deaton and his book The Great Escape (2013). 
winter (Kopala and Budden 2015). Then, there is the rise of China and India as world powers, with their almost inexhaustible reservoir of potential immigrants, a reality that cannot be ignored in the global geopolitical migration equation, though with the notable difference in that the former is an authoritarian and the latter a democratic state.

But let us also be reminded that the fate of the Western world was sealed with the outbreak of World War I, on 28 July 1914. World War I triggered the process of the Western world's decline, Der Untergang des Abendlandes, as per the title of the famous book by the German historian and philosopher Oswald Spengler (1922). Let us hope, though, that against all the odds, the implementation of stationary population policies offers a prospect of stabilizing and, perhaps, of reversing it. While remaining faithful to the principles of international solidarity and humanitarian ideals, including the plight of refugees across the world, Western governments should, at the very least, moderate the impulses for ever greater immigration and take a more critical view of diversity as a social construct in nationhood building.

Much of what has been said in this paper is open for discussion. What is certain, however, is that demography is destiny.

\section{Acknowledgements}

The author would like to thank Roderic Beaujot, Guillaume Marois, and Frank Trovato for their vigorous critique of the paper's first draft. My particular thanks go to Margret Kopala, co-author of The Dog Bone Portfolio: A Personal Odyssey into the First Kondratieff Winter of the Twenty-First Century, for her helpful substantive and editorial comments. The author is, however, solely responsible for the paper's content and for whatever imperfections remain.

\section{References}

Barysch, K. 2016. Judy Asks: Can the West regain its influence? http://carnegieeurope.eu/ strategiceurope $/$ fa $=62762$.

Beaujot, R., and M.M. Raza. 2013. Population and immigration policy, in Canadian Studies in the New Millennium, edited by P. James and M. Kasoff. Toronto: University of Toronto Press.

Camus, A. 1951. L'bomme révolté. Paris: Gallimard.

Carens, H.J. 2014. The Ethics of Immigration. Oxford: Oxford University Press.

Castles, S., H. De Haas, and M.J. Miller. 2015. The Age of Migration: International Population Movements in the Modern World. London: The Guilford Press.

Chamie, J. 2015. Gender Equality Gaps Across Borders Tell a Disturbing Story. http://passblue.com/2015/11/18/ gender-equality-gaps-accross-borders-tell-a-disturbing-story

_. 2015b. Humanity Future: Below Replacement Fertility, http://www.ipsnews.net/2015/01/humanitysfuture-below-replacement-fertility

—. 2015c. Opinion: Demography and Destiny. www.ipsnews.net/2015/10/opinion-demography-and-destiny

Coale, A. 1972. Alternative paths to a stationary population, in Demographic and Social Aspects of Population Growth, edited by C.F. Westoff and R. Parke, Jr. CPGAF Research Report. Washington: Commission on Population Growth and the American Future.

Coleman, A. David. 2006. Immigration and ethnic changes in low-fertility countries: A third demographic transition. Population and Development Review 32(3):401-46.

- 2010. Projections of the ethnic minority populations of the United Kingdom, 2006-2056. Population and Development Review 36(3):441-86.

Daly, H.E., and J.B. Cobb, Jr. 1989. For the Common Good. Boston: Beacon Press.

Conseil Économique du Canada. 1991. Incidences économiques et sociales de l'immigration. Ottawa: CEC.

Deaton, A. 2013. The Great Escape: Health, Wealth, and the Origin of Inequality. Princeton, NJ: Princeton University Press. 
Forum: Perspectives on Canadian Population — Romaniuk essay

Denton, T.F., and G.B. Spenser. 2003. Population Change and Economic Growth: The Long Term Outlook. Hamilton: McMaster University.

Derrida, J. 1992. The Other Heading: Reflection on Today's Europe. Bloomington: Indiana University Press.

Dion, P., É. Caron-Malenfant, C. Grondin, and D. Grenier. 2015. Long-term contribution of immigration to population renewal in Canada: A simulation. Population and Development Review 41(1):109-26.

Dubreuil, B., and G. Marois. 2011. Le remède imaginaire—Pourquoi l'immigration ne sawvera pas le Québec. Montreal: Boréal.

Economist, The. 2015. Blue-collar men in rich countries are in trouble: They must learn to adapt. 30 May 2017.

Ferguson, N. 2011. Civilization, The West, and the Rest. New York: Penguin Books.

Francis, D. 1982. Immigration: The Economic Case. Toronto: Key Porter Books.

Fukuyama, F. 2007. Identity and migration. Prospect Magazine 131(February).

Gauthier, A.H., and I. Hatzuis. 1997. Family benefits and fertility: An econometric analysis. Population Studies 51(3):295-306.

Gerkens, M. 2015. Paramètres fondamentaux définissant l'avenir forestier de la RDC.

Gethau, V. 2016. Populația Uniunii Europene şi migrația. http//www.contributors.ro/global-europa/populatia-uniuniieuropene-si-migrația

Gibbon, E. 1989 (1848). The Decline and Fall of the Roman Empire. London: Encyclopedia Britannica.

Habermas, J. 2000. Après l'Etat-nation: Une nouvelle constellation politique. Paris: Fayard.

Henripin, J. 1989. Naître ou ne pas être. Montreal: Institut québécois de recherche sur la culture, PUL.

-1995. La démographie et l'inconfort des considérations de caractère politique. Towards the XXI Century: Emerging socio-demographic Trends and Policy Issues. Ottawa: Federation of Canadian Demographers.

- 2011. Ma tribu, un portrait sans totem ni tabou. Montreal: Liber.

Jackson, T. 2009. Prosperity without Growth, Economics for a Finite Planet. London: Earthscan.

Judt, T. 2015. Europe: The grand illusion, in When the Facts Change: Essays 1995-2010. New York: Penguin Press.

Kerr, D., and R. Beaujot. 2016. Population Change in Canada. Don Mills, ON: Oxford University Press.

Kim, N-K. 2005. The end of Britain? Challenges from devolution, European integration and multiculturalism. Journal of International and Area Studies 12:61-80.

Kono, S. 2009. Challenges to Demographic Trilemma of Low Fertility, Ageing and Depopulation. Keynote Speech. Center for the Advancement of Working Women, Tokyo.

Kopala, M., and J. Budden. 2015.The Dog Bone Portfolio: A Personal Odyssey into the First Kondratieff Winter of the TwentyFirst Century. Toronto: BPS Books, Kindle Edition.

Légaré, J. 2001. Aging and social security program reforms: Canada in international perspective. ISUMA2(2):110-19.

Lux, A.1996. Significant policy issues for the XXIst century in light of the Symposium debate. Towards the XXIst Century: Emerging Socio-demographic Trends and Policy Issues in Canada. Ottawa: Federation of Canadian Demographers.

May, J. 2012. World Population Policies: Their Origin, Evolution, and Impact. Dordrecht: Springer.

- 2016. Interview: Pourquoi le XXIe siècle sera celui de la démographie africaine. Le Plus, 19 June. Available at http://leplus.nouvelobs.com/contribution/1528893-pourquoi-le-xxie-siecle-sera-celui-de-la-demographieafricaine.html

McDaniel, S. 1986. Canada's Aging Population. Toronto: Butterworths.

McDonald, P. 2006. Low fertility and the state: The efficacy of policy. Population and Development Review 32(3):485-510.

Mill, J.S. 1965 (1848). Principles of Political Economy. Toronto: University of Toronto Press, London: Routledge \& Kegan Paul.

Paquet, G. 2008. Deep Cultural Diversity: A Governance Challenge. Ottawa: University of Ottawa Press. 
. 2010. Immigration and the solidarity-diversity-security nexus. Optimum Online: The Journal of Public Sector Management 40(4). Available at http://www.optimumonline.ca/article.phtml?e=4JdoCAfcmUx22\&id=379

Perelli-Harris, B. 2005. The path to the lowest fertility in Ukraine. Population Studies 59(1):55-70.

Romaniuc, A. 1998. L'Europe face à son destin démographique. Reflets et perspectives de la vie économique (De Boeck Université, Belgium) 37:83-99.

Romaniuk, A. 2009. "Stationary Population as Theoretical Concept and As Policy Vision," presented at the International Conference on Population, September 2009 in Marrakesh, Morocco, organized by the International Union for Scientific Study of Population (IUSSP).

- 2010. Fertility in the age of demographic maturity: An essay. Canadian Studies in Population 34(3-4):283-95.

- 2011. Persistence of high fertility in tropical Africa: The case of the Democratic Republic of the Congo. Population and Development Review 37(1):1-28.

- 2012. Stationary population as a policy vision. Optimum Online: The Journal of Public Sector Management 42(1). Available at http://www.optimumonline.ca/print.phtml?e=4JdoCAfcmUx22\&id=405

- 2013. Book review of Glimpses of Indian Historical Demography by Parameswara Krishnan (Delhi: B.R. Publishing Corporation 2010). Canadian Studies in Population 40(3-4):248-51.

Simmons, A.B. 2010. Immigration and Canada: Global and Transnational Perspectives. Toronto: Canadian Scholars' Press.

Smith, T. 2000. Foreign Attachments: The Power of Ethnic Group in the Making of American Foreign Policy. Cambridge, MA: Harvard University Press.

Sowell, T. 1983. The Economics and Politics of Race: An International Perspective. New York: Quill. 1996. Migration and Culture: A World View. New York: Basic Books.

Spengler, O. 1922. Der Untergang des Abendlandes. Munich: Beck.

Suzuki, D. 2011. The Sacred Balance: Rediscovering our Place in Nature. Vancouver: Greystone Books.

Suzuki, D., and D.R. Taylor. 2009. The Big Picture: Reflection on Science, Humanity, and a Quickly Changing Planet. Vancouver: Greystone Books.

Statcan (Statistics Canada). 2001. National Household Survey. Ottawa: Statistics Canada.

Termote, Marc. 2011. The efficiency of immigration and integration policies. Population Review 50(2):90-108.

Tribalat, M. 1955. Faire France: une grande enquête sur les immigrants et leurs enfants. Paris: Éditions La Découverte.

- 2010. Les Yeux grands fermés: l'immigration en France. Paris: Denoël.

- 2013. Assimilation: la fin du modèle français. Paris: Éditions du Toucan.

Trovato, F. 2015. Canada's Population in the Global Context: An Introduction to Social Demography. 2nd edn. Toronto: Oxford University Press.

Zemmour, É. 2014. Le suicide français. Paris: Éditions Albin Michel.

\section{Additional reading}

Demeny, P. 2008. A clouded view of Europe's demographic future. Vienna Yearbook of Population Research 6:27-35.

Henripin, J.. 2004. Pour une politique de population. Montreal: Les Éditions Varia.

Henripin, J., P-M. Hout, E. Lapierre-Adamcyk, and N. Marcel-Gratton. 1981. Les enfants qu'on n'a plus. Montreal: Les Presses de l'Université de Montréal.

Lux, A. 1983. Un Québec qui vieillit: Perspectives pour le XXI siècle. Recherches sociographiques 24(3):335-77.

. 1991. Le poids du vieillissement: idéologie, paradoxes et stratégies, in La population du Québec d'hier à demain by J. Henripin and Y. Martin. Montreal: Les Presses de l'Université de Montréal, p. 109-38.

Yuzyk, P. 1973. For a Better Canada, Toronto: Ukrainian National Association, Canadian Office. 